\title{
Review Article \\ Descriptions of New Species of Leucotrichiinae (Trichoptera: Hydroptilidae) from Brazil
}

\author{
Robin E. Thomson ${ }^{1,2}$ \\ ${ }^{1}$ Department of Entomology, University of Minnesota, 219 Hodson Hall, 1980 Folwell Avenue, St. Paul, MN 55108, USA \\ ${ }^{2}$ Department of Entomology, National Museum of Natural History, Smithsonian Institution, Washington, DC 20013, USA
}

Correspondence should be addressed to Robin E. Thomson, thom1514@umn.edu

Received 13 February 2012; Accepted 27 March 2012

Academic Editor: Ai-Ping Liang

Copyright ( 2012 Robin E. Thomson. This is an open access article distributed under the Creative Commons Attribution License, which permits unrestricted use, distribution, and reproduction in any medium, provided the original work is properly cited.

Two new species of Hydroptilidae (Trichoptera) from Brazil are described: Betrichia alibrachia sp. n. and Leucotrichia bicornuta sp.n. Both genera are members of the subfamily Leucotrichiinae. Illustrations of male genitalia are provided with each description. These additions bring the total world fauna of Betrichia to 9 species and Leucotrichia to 29 species.

\section{Introduction}

The subfamily Leucotrichiinae (type genus Leucotrichia Mosely, 1934) was established by Flint (1970) and currently contains 16 genera: Abtrichia, Acostatrichia, Alisotrichia, Anchitrichia, Ascotrichia, Betrichia, Celaenotrichia, Cerasmatrichia, Ceratotrichia, Costatrichia, Eutonella, Leucotrichia, Mejicanotrichia, Peltopsyche, Scelobotrichia, and Zumatrichia $[1,2]$. The distribution of the subfamily is limited to the New World and found predominantly in Central America $[3,4]$.

Mosely (1939) established the genus Betrichia for a single species, Betrichia zilbra, from Brazil (Santa Catarina) [5]. No exact reasons were stated, but presumably the genus was erected on account of venational, antennal, and general male genitalic features [3]. Additional species and distributions have been provided by Angrisano, Flint, and Olah and Johanson [6-10]. Up to and including species described by Olah and Johanson in 2011, Betrichia contained a total of 8 extant species (Table 1) $[2,10]$. As a genus, its distribution is limited to eastern South America (Table 1) [4]. Immature stages are unknown [3]. Adults are attracted to lights and can generally be found near lowland rivers [4].

Mosely (1934) established the genus Leucotrichia for a single species, Leucotrichia melleopicta, from Mexico (Tabasco) [11]. Additional species descriptions and distributions have been provided by Angrisano and Burgos, Banks, Botosaneanu (in Botosaneanu and Alkins-Koo),
Bueno-Soria, Bueno-Soria et al., Flint, Olah and Johanson, Ross, Rueda Martín, Sattler and Sykora, and Wells and Wichard [1, 10, 12-23]. Up to and including species described by Olah and Johanson and Rueda Martín in 2011, Leucotrichia contained a total of 28 extant species (Table 1) $[2,10,20]$. The distribution of the genus includes most of the continental USA, the Greater and southern Lesser Antilles, Central America, and northern South America (Table 2) [4]. A single fossil species, Leucotrichia adela, is known from Dominican amber [22]. Adults occasionally come to light but are usually taken by net during the day from marginal foliage [4].

In this paper, I describe two new species, Betrichia alibrachia and Leucotrichia bicornuta, from Brazil. This brings the total world fauna of Betrichia to 9 and of Leucotrichia to 29.

\section{Taxonomy}

2.1. Leucotrichiinae Flint, 1970. Past attempts at dividing Hydroptilidae into suprageneric units based primarily on larval morphology generally have produced groups of genera that were not or could not be placed into easily distinguishable groups [1]. Leucotrichia and its closely related genera have often proven to be a somewhat aberrant unit in these attempts. Flint stated that, although there was no single characteristic that could be used to consistently separate 
Table 1: Species and distributions of Betrichia and Leucotrichia.

\begin{tabular}{|c|c|}
\hline Species & Distribution \\
\hline \multicolumn{2}{|c|}{ Betrichia } \\
\hline argentinica Flint 1972 & Argentina, Uruguay \\
\hline bispinosa Flint 1974 & Surinam \\
\hline hamulifera Flint 1983 & Argentina, Paraguay, Uruguay \\
\hline longistyla Flint 1983 & Brazil \\
\hline occidentalis Flint 1974 & Surinam \\
\hline rovatka Olah and Johanson 2011 & French Guiana \\
\hline uruguayensis Angrisano 1995 & Uruguay \\
\hline zilbra Mosely 1939 & Brazil, Uruguay \\
\hline \multicolumn{2}{|c|}{ Leucotrichia } \\
\hline alisensis Rueda-Martín 2011 & Argentina \\
\hline ayura Flint 1991 & Colombia \\
\hline botosaneanui Flint 1996 & Tobago, Trinidad \\
\hline brasiliana Sattler and Sykora 1977 & Brazil \\
\hline brochophora Flint 1991 & Colombia \\
\hline chiriquiensis Flint 1970 & Panama \\
\hline dinamica Bueno-Soria 2010 & Mexico \\
\hline extraordinaria Bueno-Soria et al. 2001 & Mexico \\
\hline fairchildi Flint 1970 & Colombia, Grenada, Panama, Tobago, Trinidad, Venezuela \\
\hline forrota Olah and Johanson 2011 & Peru, Ecuador \\
\hline gomezi Flint 1970 & Dominican Republic \\
\hline imitator Flint 1970 & Costa Rica, Guatemala, Mexico \\
\hline inflaticornis Botosaneanu 1993 & Trinidad \\
\hline inops Flint 1991 & Colombia \\
\hline interrupta Flint 1991 & Colombia \\
\hline laposka Olah and Johanson 2011 & Peru \\
\hline lerma Angrisano and Burgos 2002 & Argentina \\
\hline limpia Ross 1944 & Mexico, U.S.A. \\
\hline melleopicta Mosely 1934 & Mexico, Venezuela \\
\hline mutica Flint 1991 & Colombia \\
\hline padera Flint 1991 & Colombia \\
\hline pictipes Banks 1911 & U.S.A., Mexico \\
\hline sarita Ross 1944 & Costa Rica, El Salvador, Guatemala, Mexico, U.S.A. \\
\hline termitiformis Botosaneanu 1993 & Trinidad \\
\hline tritoven Flint 1996 & Tobago, Trinidad, Venezuela \\
\hline tubifex Flint 1964 & Dominican Republic, Haiti, Jamaica, Puerto Rico \\
\hline viridis Flint 1967 & El Salvador, Guatemala, Mexico, Panama \\
\hline yungarum Angrisano and Burgos 2002 & Argentina \\
\hline
\end{tabular}

adults from other subfamilies, a combination of characters were diagnostic for Leucotrichiinae when present [1]. These characters included the reduction of ocelli to 2 , the presence of modified setae, the presence of a basal costal pouch on the forewing, and something characteristic in the form of the male genitalia that was hard to define exactly [1], but likely includes the "window" and basal loop medially on the phallic apparatus. The character that was absolutely distinctive and primarily responsible for Flint's establishment of
Leucotrichiinae was the larval shelter; the shelter is no more than a dorsal covering nor is it moveable, characteristics not possessed by any other genus [1].

In her revision of the genera of Hydroptilidae, Marshall recognized only two subfamilies: Ptilocolepinae and Hydroptilinae [3]. Leucotrichiini was included within Hydroptilinae, due to the many features characteristic of Hydroptilinae in general [3]. Marshall also stated that although Leucotrichiini does form a distinct group within Hydroptilinae, it was 
TABle 2: Species groups of Leucotrichia.

\begin{tabular}{lcc}
\hline $\begin{array}{l}\text { L. melleopicta } \\
\text { species group }\end{array}$ & $\begin{array}{c}\text { L. pictipes species } \\
\text { group }\end{array}$ & Incertae sedis \\
\hline L. ayura & L. fairchildi & L. alisensis \\
L. brochophora & L. imitator & L. botosaneanui \\
L. chiriquiensis & L. pictipes & L. brasiliana \\
L. dinamica & L. sarita & L. forrota \\
L. extraordinaria & & L. laposka \\
L. gomezi & & L. lerma \\
L. inflaticornis & & L. mutica \\
L. inops & & L. termitiformis \\
L. interrupta & L. tritoven \\
L. limpia & & L. yungarum \\
L. melleopicta & & \\
L. padera & & \\
L. tubifex & & \\
L. viridis & & \\
\hline
\end{tabular}

impossible to exactly define the genera, since species from two or more genera often key out with one another in generic-level keys [3].

Malicky elevated Ptilocolepinae to family rank Ptilocolepidae, leaving only one subfamily of six tribes in Hydroptilidae [24]. This effectively raised each tribe back to the subfamily status originally designated by Flint.

2.2. Betrichia Mosely, 1939. In the original description, Mosely mentioned the presence of ocelli (the type-specimen bears 2), short antennae with a long basal joint, elongate wings with acute produced apices, and a 1, 3, 4 tibial spur formula as being part of the diagnosis of the genus [5]. Maxillary palpi were missing from the holotype, the single specimen that was examined, and so was unavailable for description. Genitalic features and a forewing measurement of $3 \mathrm{~mm}$ were included in the species description of B. zilbra [5]. Among the genitalic features mentioned were the deeply excised apical margin of tergite VIII, the shallowly excised apical margin of tergite IX with apical angles produced into a pair of irregular rounded lobes, a phallus with a pair of stout sheaths, and a slender process on sternite VII [5]. Wing venation and male genitalia were illustrated in the description of the type-species [5].

In her review of the genera of Hydroptilidae, Marshall concluded that the combination of features given in the original generic description was not unique to Betrichia and that there are no precise diagnostic features that distinguish it from other genera $[3,4]$. Of the additional species added to the genus, most differ noticeably in some way from the type-species. For example, Betrichia argentinica shares similar genitalic features with the type-species, but also bears 3 ocelli and simple antennae. The male genitalic features of Betrichia surinamensis differ greatly from that of the typespecies and Betrichia bispinosa bears a basal costal pouch not found throughout the genus. Flint has stated that the establishment of additional genera to sort out such variation should wait until the South American Trichoptera fauna is better understood [8]. According to Marshall, all small leucotrichiine genera, such as Betrichia, should be placed in a group together, as characters originally diagnosed as generic features have proven to be specific as additional species have been described [3]. Marshall's summary of male genitalic features reflects the variation now found within the genus, including features such as a variable subgenital plate, variable tergite X, and sternite VIII and segment IX each with or without posterolateral processes [3].

2.3. Leucotrichia Mosely, 1934. In the original description, Mosely mentioned the presence of ocelli, antennal joints grouped in series of white and brown, a well-developed frenulum on the hindwing, arising from the subcosta, very densely setose legs, and a 1, 3, 4 tibial spur formula as being part of the generic diagnosis [11]. Maxillary palpi were mentioned as difficult to observe. Male genitalic features and a forewing measurement of $2 \mathrm{~mm}$ were included in the species description of L. melleopicta [11]. Among the genitalic features mentioned were the flattened terminal dorsal segment covering the genitalia, the deeply excised terminal ventral segment bearing setose margins, a spade-shaped "penis sheath", and a slender process on the penultimate abdominal segment [11]. Wing venation and male genitalia were illustrated in the description of the type-species [11].

As additional new species were described and placed in Leucotrichia, Flint noted that, despite variation in antennae, number of ocelli, and dorsal structure of the head, there were certain other features that could be used to unite 2 species groups within the genus [1]. Characters that Flint found distinguished the L. melleopicta species group include males bearing 3 ocelli, a mesoventral process on sternum VII, an unmodified head (except for L. chiriquiensis), and 1 or 2 large areas of greenish or whitish setae on the forewings [1]. Characters that Flint found distinguished the L. pictipes species group include males bearing 2 ocelli, either a brush of setae or a point on sternum VII, a modified head (except for L. imitator), and spots or linear greenish or whitish marks on the forewings [1].

Flint also provided a generic-level diagnosis, including additional characters not in the original diagnosis. Mentioned, among other features, were the pentagonal metascutellum, the heavily sclerotized trianguloid plate of tergite $\mathrm{X}$, the subgenital plate extending ventrally from the ventral angles of tergite $\mathrm{X}$ to the base of the inferior appendages, the subapical spine of the inferior appendages, and the midlength complex of the phallus [1]. Flint did not mention the wings in his generic diagnosis, while Marshall stated in her review of hydroptilid genera that the wings are unmodified, but made no mention of a well-developed frenulum on the hindwing $[1,3]$.

Larvae have been associated with some species in the genus, but many are still unassociated [4]. The larvae are generally typical of the Leucotrichiinae but can be distinguished by their rugose or papillate head, single tarsal claw, and femora bearing spiniform dorsal setae [3]. The larvae, which are strongly depressed and may reach up 
to $5 \mathrm{~mm}$ in length, are free-living and found in running water on the upper surface of rocks, grazing on periphyton, until the final instar $[25,26]$. During this final retreatdwelling instar, they also display extreme lateral distention of abdominal segments V-VII [26]. The silken retreats are generally flattened ovals up to $5.5 \mathrm{~mm}$ in length, slightly domed, with a circular opening at each end, attached tightly to rocks in fast flowing waters $[3,4,26]$.

\section{Materials and Methods}

Morphological terminology used for male genitalia of specimens follows that of Marshall [2]. For simplicity, paired structures are discussed in the singular. Procedures for specimen preparation followed those explained in detail by Blahnik et al. [27]. For specimen examination and illustration, cleared genitalia were placed in a watch glass with glycerin and small glass beads. The glass beads held the genitalia in place and allowed structures to be viewed in precise lateral, dorsal, and ventral positions. Genitalia were examined with an Olympus BX41 compound microscope at 250-500x magnification. Structures were traced in pencil with the use of an Olympus model U-DA drawing attachment mounted on the microscope. Pencil sketches were then scanned (Fujitsu ScanSnap S1500M scanner), edited in Adobe Photoshop (v. 9.0.2, Adobe Systems Inc.), and used as a template in Adobe Illustrator (v. 13.0.2, Adobe Systems Inc.) to be digitally inked. Electronic "drawing" was completed with the aid of a graphics tablet (Bamboo Fun, Wacom Company, Limited). Illustrations shown in Figures 1 and 2 were produced from holotype specimens. Species descriptions were constructed using the program DELTA [28] and specimen management followed the procedures outlined by Holzenthal and Andersen [29]. Individual specimens examined during the study were associated with a barcode label ( 4 mil polyester, $8 \times 14 \mathrm{~mm}$, code 49 ) bearing a unique alphanumeric sequence beginning with the prefix UMSP. Vials of alcohol containing multiple specimens were given a single barcode label to represent all those in the vial. The prefix is not meant to imply ownership by the University of Minnesota Insect Collection (UMSP), but only to indicate that the specimen was databased at that collection. Types of species described and other material examined are deposited in the Coleção Entomológica Professor José Alfredo Pinheiro Dutra, Departamento de Zoologia, Universidade Federal do Rio de Janeiro, Rio de Janeiro (DZRJ), and the University of Minnesota Insect Collection, St Paul, Minnesota (UMSP).

\section{New Species Descriptions}

\subsection{Betrichia alibrachia sp.n. (Figure 1)}

Material. Holotype male: Brazil: Rio de Janeiro: Resende, Ribeirás do Palmital, $22^{\circ} 25^{\prime} 26.2^{\prime \prime} \mathrm{S}, 44^{\circ} 44^{\prime} 21.6^{\prime \prime} \mathrm{W}, 969 \mathrm{~m}$, 8.iii.2008, white light, collected by Nessimian, Dumas, de Souza, and Braga (in alcohol) (UMSP0000140290) (DZRJ). Paratypes: same data as holotype (9 males) (in alcohol) (DZRJ); Resende, Riacho no km 4 BR 354, $22^{\circ} 23^{\prime} 20^{\prime \prime} \mathrm{S}$, $44^{\circ} 45^{\prime} 16^{\prime \prime} \mathrm{W}, 1411 \mathrm{~m}$, 9.iii.2008, white light, collected by Nessimian, Dumas, de Souza, and Braga (1 male) (in alcohol) (DZRJ); Itatiaia, Parque Nacional do Itatiaia, ponte no Lago Azul, $22^{\circ} 27^{\prime} 02.8^{\prime \prime} \mathrm{S}, 44^{\circ} 36^{\prime} 50.2^{\prime \prime} \mathrm{W}, 29$. viii.2009, UV light, collected by Cardosio-Costa and de Souza (1 male) (in alcohol) (DZRJ); Resende, Ribeirás do Palmital, $22^{\circ} 25^{\prime} 26.2^{\prime \prime} \mathrm{S}, 44^{\circ} 44^{\prime} 21.6^{\prime \prime} \mathrm{W}, 969 \mathrm{~m}, 8 . i i i .2008$, UV light, collected by Nessimian, Dumas, de Souza, and Braga (2 males) (in alcohol) (UMSP); Nova Friburgo, Macaé de Cima, Rio Macaé, $22^{\circ} 24^{\prime} 46.0^{\prime \prime} \mathrm{S}, 42^{\circ} 31^{\prime} 16.2^{\prime \prime} \mathrm{W}$, 13.ix.2009, collected by Santos ( 1 male, 1 female) (in alcohol) (DZRJ).

Description Male. Length of forewing 1.8-2.6 $\mathrm{mm}(n=$ 9). Head unmodified, with 3 ocelli; antennae unmodified. Wings unmodified. Tibial spur count 1, 3, 4. Color in alcohol brown, denuded. Genitalia. Abdominal sternum VII mesoventral process acute. Segment VIII anterolateral margin acute, posterolateral margin with 3 projections, 1st and 3rd slender, elongate with single prominent seta, 2nd less pronounced, with single seta; in ventral view posterior margin acutely concave. Segment IX anterolateral margin with 2 pairs of elongate apodemes extended anteriorly, as in Figures 1(a) and 1(c), posterolateral margin setose, rounded; with elongate mesolateral rasp-like structure within membranous layer, extended anteriorly into segment VI, with triangular sclerotized structure at base of membranous layer, apex curving dorsad; dorsally segment IX with anterior margin concave. Subgenital plate not apparent. Inferior appendage apparently fused basally to segment IX, elongate, quadrate basodorsally, apex subacute, extended posteriorly further than tergum X. Tergum X membranous, rounded dorsally, apex emarginate in lateral view. Phallus tubular basally, with median complex bearing basal loop and pair of circular "windows," apex with rounded ventral membranous projection.

Diagnosis. This species has several features that distinguish it from all other species in the genus. It lacks both an apparent subgenital plate and apical spines or sclerites on the phallus. It also bears an elongate rasp-like process extending anteriorly from segment IX. This process is not present elsewhere in the genus, or in any other genera of which I am aware.

Etymology. Alius, Latin for "another"; brachium, Latin for "arm", referring to the very unusual rasp-like structure extending anteriorly from segment IX.

\subsection{Leucotrichia bicornuta sp.n. (Figure 2)}

Material. Holotype male: Brazil, Rio de Janeiro, Panedo, Rio

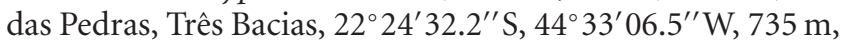
6.iii.2008, collected by Nessimian, Dumas, de Souza, and Braga (in alcohol) (UMSP000014084) (DZRJ). Paratypes: Brazil, Rio de Janeiro, Itatiaia, Parque Nacional do Itatiaia, Rio Camp Belo, $22^{\circ} 27^{\prime} 17.32^{\prime \prime} \mathrm{S}, 44^{\circ} 36^{\prime} 37.47^{\prime \prime} \mathrm{W}, 705 \mathrm{~m}$, 13.iv.2007, light, collected by Santos, Dumas, Ferreira, Jr., and Nessimian (2 males, 1 female) (in alcohol) (DZRJ). 


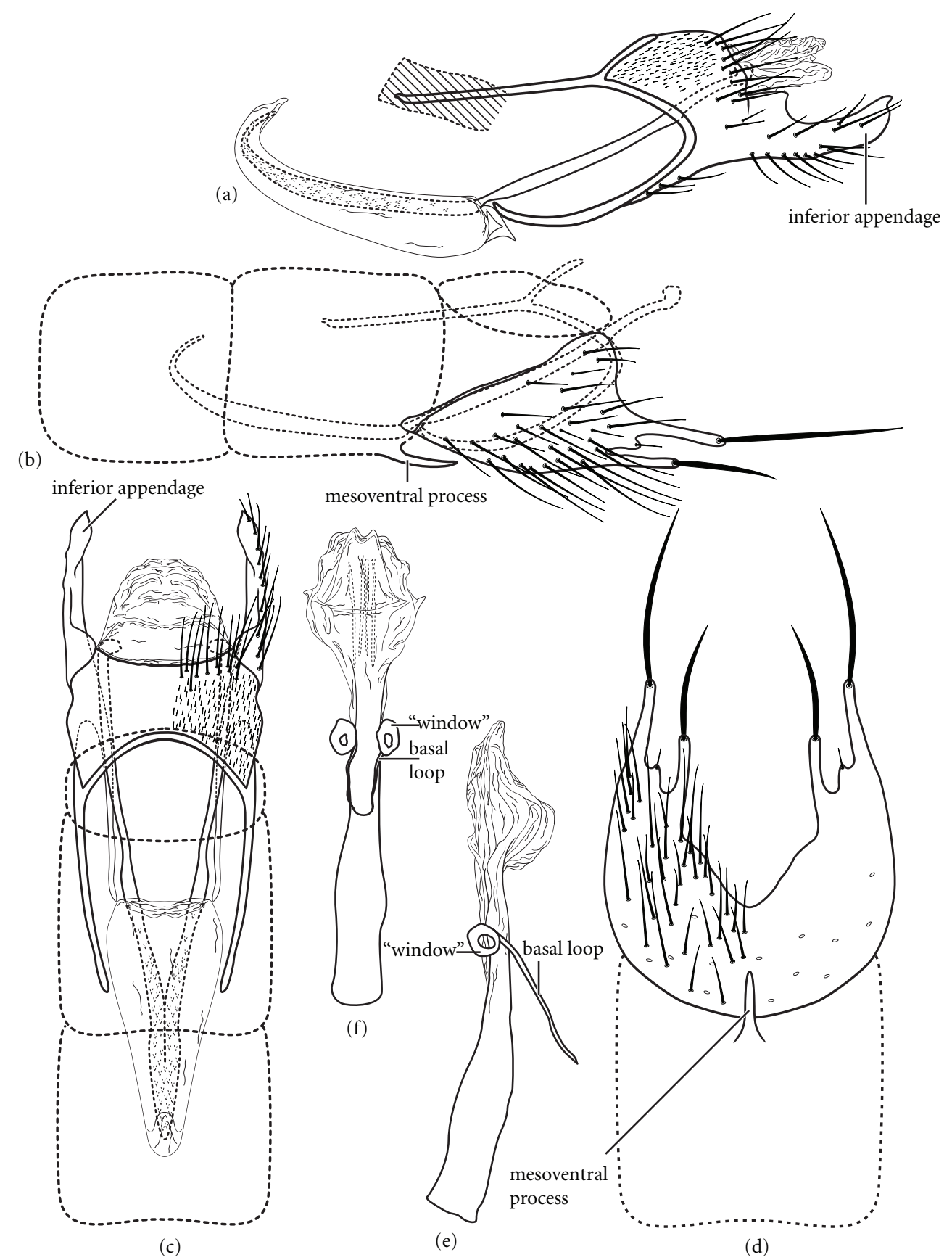

FIgURE 1: Betrichia alibrachia sp.n., male genitalia: (a) segments IX-X, left lateral (base of phallus crosshatched); (b) segments VI-VIII and segment IX anterolateral margin, left lateral; (c) segments VI-X, dorsal; (d) segments VII-VIII, ventral; (e) phallus, left lateral; (f) phallus, dorsal.

Description Male. Length of forewing 2.5-3.4 mm $(n=3)$. Head unmodified, with 3 ocelli; antennae unmodified. Tibial spur count 1, 3, 4. Color in alcohol brown, denuded. Genitalia. Abdominal sternum VII mesoventral process basally broad, rounded apically. Segment VIII anterolateral margin convex, posterolateral margin with single rounded projection bearing prominent setae; in ventral view posterior margin broadly concave. Segment IX anterolateral margin broadly produced dorsolaterally, posterolateral margin setose, broadly convex; dorsally with anterior margin broadly convex. Subgenital plate extending from ventral angle of tergum $\mathrm{X}$, ventral arm extending to base of inferior appendage. Inferior appendage without setae, narrow basally, not extended posteriorly past tergum $\mathrm{X}$, with small spine dorsally, apex curving dorsad, in ventral view apex with rounded emargination. Tergum $\mathrm{X}$ with semielliptic sclerite 


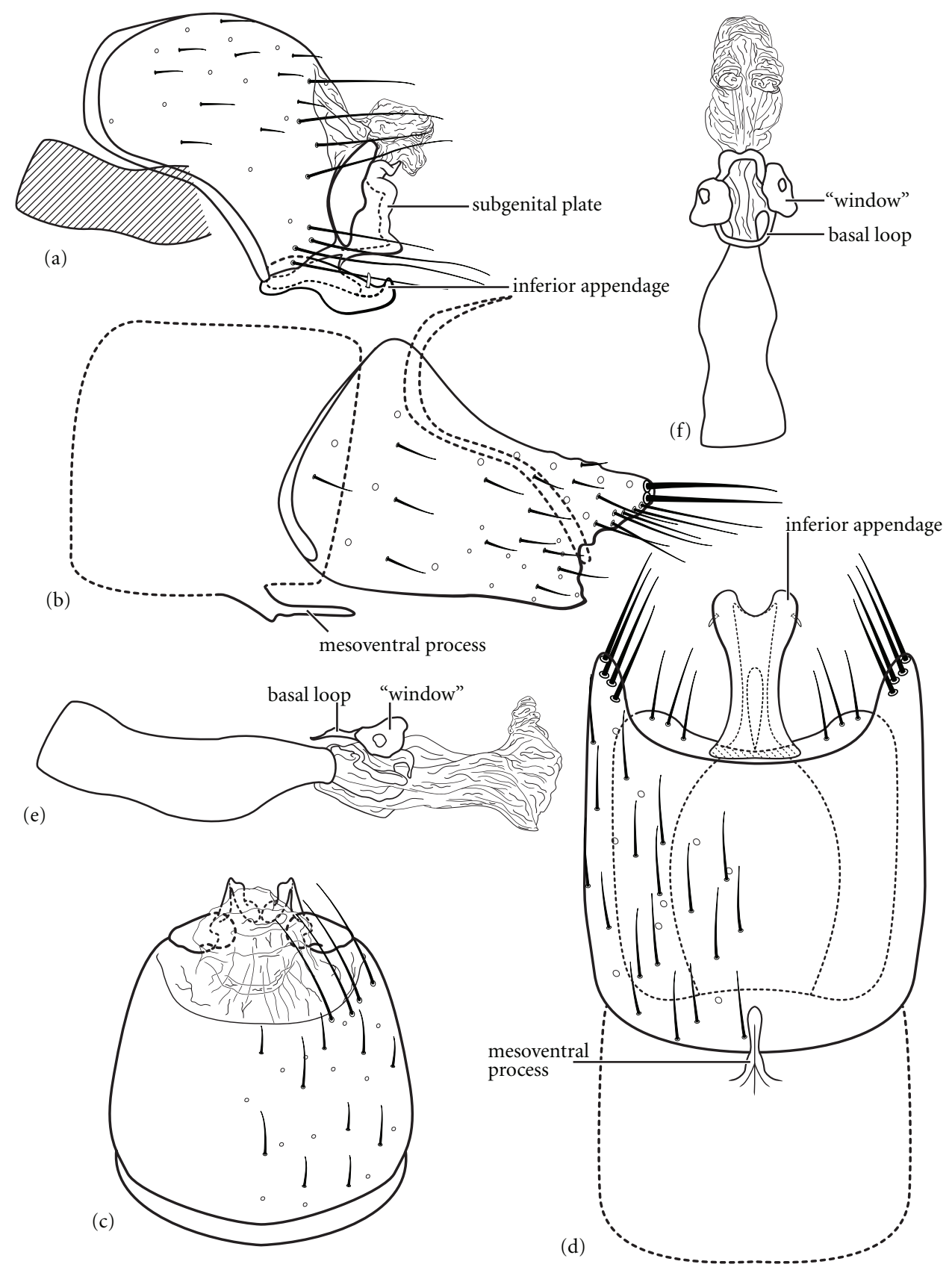

FIGURE 2: Leucotrichia bicornuta sp.n., male genitalia: (a) segments IX-X, left lateral (base of phallus crosshatched); (b) segments VII-VIII and segment IX anterolateral margin, left lateral; (c) segments IX-X, dorsal; (d) segments VII-IX, ventral; (e) phallus, left lateral; (f) phallus, dorsal.

with tridentate posterior margin; with membranous suborbicular projection apically. Phallus tubular basally, with median complex bearing basal loop and pair of circular "windows," membranous apex bearing paired dorsal lobes.

Diagnosis. This species is most similar to Leucotrichia ayura Flint, 1991, a member of the Leucotrichia melleopicta species group [18]. Leucotrichia bicornuta is distinguished by the ventral arm of the subgenital plate, which does not project as far posteriad as that of L. ayura and then bends dorsad instead of remaining straight. Leucotrichia bicornuta is also distinguished by the lack of dorsal sclerites or apical spines on the phallus. Also, in L. bicornuta, the inferior appendages are broadly fused mesally; in L. ayura they are separate.

Etymology. Bi, Latin for "double"; cornutus, Latin for "horned", referring to the 2 apicodorsal lobes of the phallus.

\section{Acknowledgments}

The author is grateful to Allan Paulo Moreira Santos and Jorge Luiz Nessimian, Universidade Federal do Rio de Janeiro 
for permission to describe the new species collected during their research in Brazil. Dr. OS Flint, Jr., Smithsonian Institution, Dr. RW Holzenthal, University of Minnesota, and 2 anonymous reviewers provided invaluable comments on the identity and placement of these new species and reviewed the paper. This material is based on work supported by the National Science Foundation Grant no. 0816865 to KM Kjer and RW Holzenthal. The author was supported also by a CIC Smithsonian Institution Fellowship. This support is gratefully acknowledged.

\section{References}

[1] O. S. Flint Jr., "Studies of Neotropical caddisflies, X: Leucotrichia and related genera from North and Central America (Trichoptera: Hydroptildiae)," Smithsonian Contributions to Zoology, vol. 60, pp. 1-64, 1970.

[2] J. C. Morse, "Trichoptera World Checklist," 2012, http://www .clemson.edu/cafls/departments/esps/database/trichopt/.

[3] J. E. Marshall, "A review of the genera of the Hydroptilidae (Trichoptera)," Bulletin of the British Museum (Natural History) Entomology Series, vol. 39, pp. 135-239, 1979.

[4] O. S. Flint Jr., R. W. Holzenthal, and S. C. Harris, Catalog of the Neotropical Caddisflies (Insecta: Trichoptera), Special Publication of the Ohio Biological Survey, Columbus, Ohio, USA, 1999.

[5] M. E. Mosely, "The Brazilian Hydroptilidae (Trichoptera)," Novitates Zoologicae, vol. 41, pp. 217-239, 1939.

[6] E. B. Angrisano, "Contribucíon al conocimiento de los Trichoptera del Uruguay. II. Familia Hydroptilidae," Revista Brasileira de Entomologia, vol. 39, pp. 501-516, 1995.

[7] O. S. Flint Jr., "Studies of Neotropical caddisflies, XIV: on a collection from northern Argentina," Proceedings of the Biological Society of Washington, vol. 85, pp. 223-248, 1972.

[8] O. S. Flint Jr., "Studies of Neotropical caddisflies, XV: the Trichoptera of Surinam," Studies on the Fauna of Suriname and other Guyanas, vol. 14, pp. 1-151, 1974.

[9] O. S. Flint Jr., "Studies of Neotropical caddisflies, XXXIII: new species from austral South America (Trichoptera)," Smithsonian Contributions to Zoology, vol. 377, pp. 1-100, 1983.

[10] J. Olah and K. A. Johanson, "New Neotropical Hydroptilidae (Trichoptera)," Annales Historico-Naturales Musei Nationalis Hungarici, vol. 103, pp. 117-255, 2011.

[11] M. E. Mosely, "New exotic Hydroptilidae," Transactions of the Royal Entomological Society of London, vol. 82, pp. 137-163, 1934.

[12] N. Banks, "Description of new species of North American neutoperoid insects," Transactions of the American Entomological Society, vol. 37, pp. 335-360, 1911.

[13] L. Botosaneanu and M. Alkins-Koo, "The caddis flies (Insecta: Trichoptera) of Trinidad and Tobago, West Indies," Bulletin de l'Institut des Sciences Naturelles de Belgique, Entomologie, vol. 63, pp. 5-45, 1993.

[14] J. Bueno-Soria, "Some new Trichoptera (Glossosomatidae, Hydroptilidae, Hydropsychidae and Polycentropodidae) from Mexico," Proceedings of the Entomological Society of Washington, vol. 112, no. 1, pp. 22-31, 2010.

[15] J. Bueno-Soria, S. Santiago-Fragoso, and R. Barba-Alvarez, "Studies in aquatic insects, XVIII: New species and new record of caddisflies (Trichoptera) from Mexico," Entomological News, vol. 112, no. 3, pp. 145-158, 2001.
[16] O. S. Flint Jr., "The caddisflies (Trichoptera) of Puerto Rico," University of Puerto Rico, Agricultural Experiment Station, Technical Paper, vol. 40, pp. 1-80, 1964.

[17] O. S. Flint Jr., "Studies of Neotropical caddisflies, XLV: the taxonomy, phenology, and faunistics of the Trichoptera of Antioquia, Colombia," Smithsonian Contributions to Zoology, vol. 520, pp. 1-113, 1991.

[18] O. S. Flint Jr., "Studies of neotropical caddisflies LV: Trichoptera of Trinidad and Tobago," Transactions of the American Entomological Society, vol. 122, no. 2-3, pp. 67-113, 1996.

[19] H. H. Ross, "The caddisflies or Trichoptera of Illinois," Bulletin of the Illinois Natural History Survey, vol. 23, pp. 1-326, 1944.

[20] P. A. Rueda Martín, "New Hydroptilidae and new records from north-western Argentina and Bolivia (Trichoptera: Hydroptilidae)," Aquatic Insects, vol. 33, pp. 1-11, 2011.

[21] W. Sattler and J. L. Sykora, "Über eine, besonders durch ihr Bauinstinkt, merkwürdige neotropische KöcherfliegeLeucotrichia brasiliana n. sp," Amazonia, vol. 6, pp. 137-255, 1977.

[22] A. Wells and W. Wichard, "Caddisflies of Dominican amber VI. Hydroptilidae (Trichoptera)," Studies on Neotropical Fauna \& Environment, vol. 24, no. 1, pp. 41-51, 1989.

[23] E. B. Angrisano and G. N. Burgos, "Contribución para el conocimiento de los Leucotrichiini (Trichoptera: Hydroptilidae). Tres especies nuevas de la Argentina," Revista de la Sociedad Entomológica Argentina, vol. 61, pp. 103-109, 2002.

[24] H. Malicky, "Notes on the taxonomy of Rhadicoleptus, Ptilocolepus and Pseudoneureclipsis," Braueria, vol. 28, pp. 19-20, 2001.

[25] J. R. McAuliffe, "Behavior and life history of Leucotrichia pictipes (Banks) ( Trichoptera: Hydroptilidae) with special emphasis on case reoccupancy," Canadian Journal of Zoology, vol. 60, no. 7, pp. 1557-1561, 1982.

[26] G. B. Wiggins, "Larvae of the North American Caddisfly Genera (Trichoptera)," pp. University of Toronto PressToronto, Canada, 1996.

[27] R. J. Blahnik, R. W. Holzenthal, and A. Prather, "The lactic acid method for clearing Trichoptera genitalia," in Proceedings of the 12th International Symposium on Trichoptera, J. BuenoSoria, R. Barba-Alvarez, and B. Armitage, Eds., The Caddis Press, Columbus, Ohio, USA, 2007.

[28] M. J. Dallwitz, T. A. Paine, and E. J. Zurcher, "User's guide to DELTA Editor," 2012, http://delta-intkey.com/.

[29] R. W. Holzenthal and T. Andersen, "The caddisfly genus Triaenodes in the Neotropics (Trichoptera: Leptoceridae)," Zootaxa, vol. 511, pp. 1-80, 2004. 

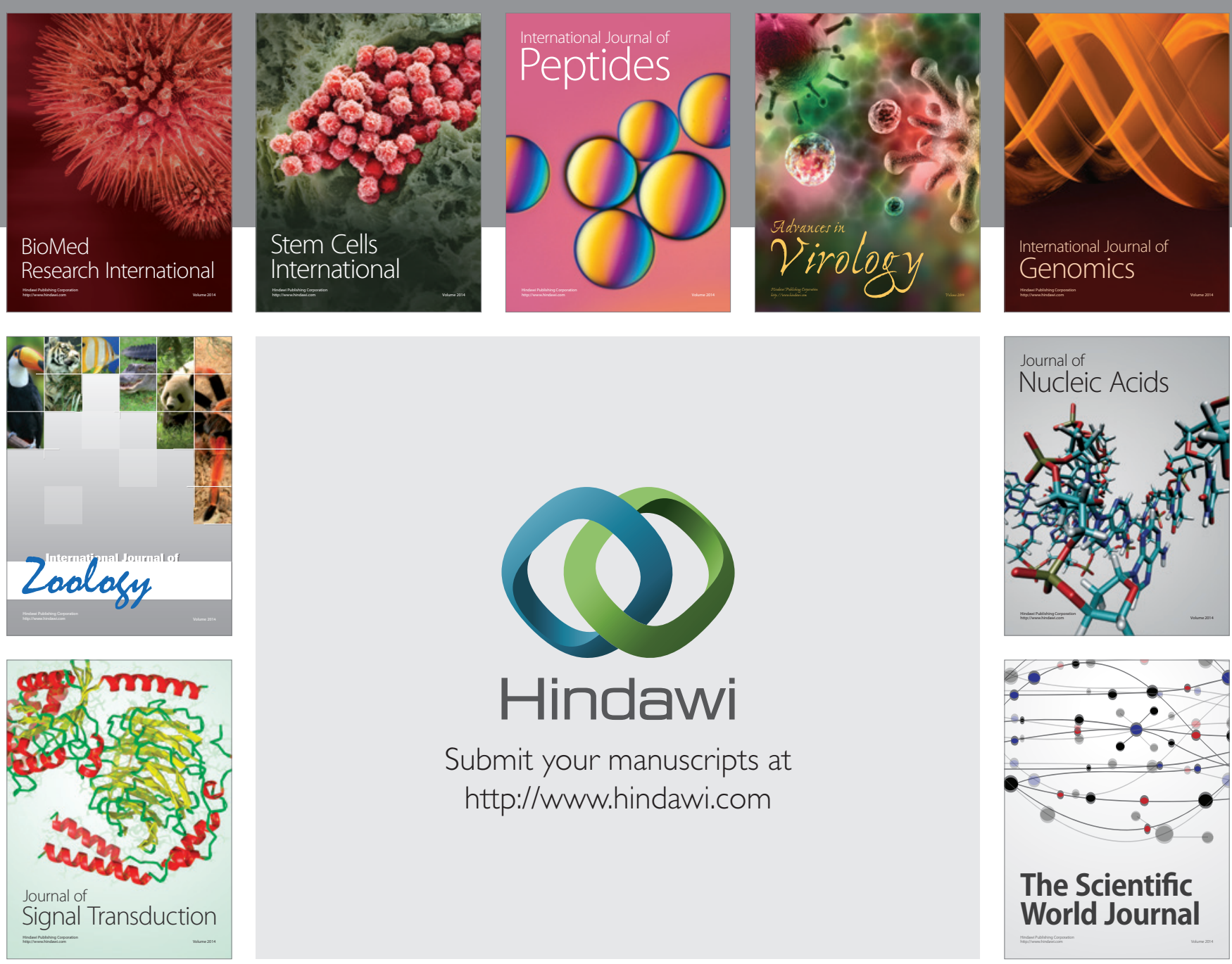

Submit your manuscripts at

http://www.hindawi.com
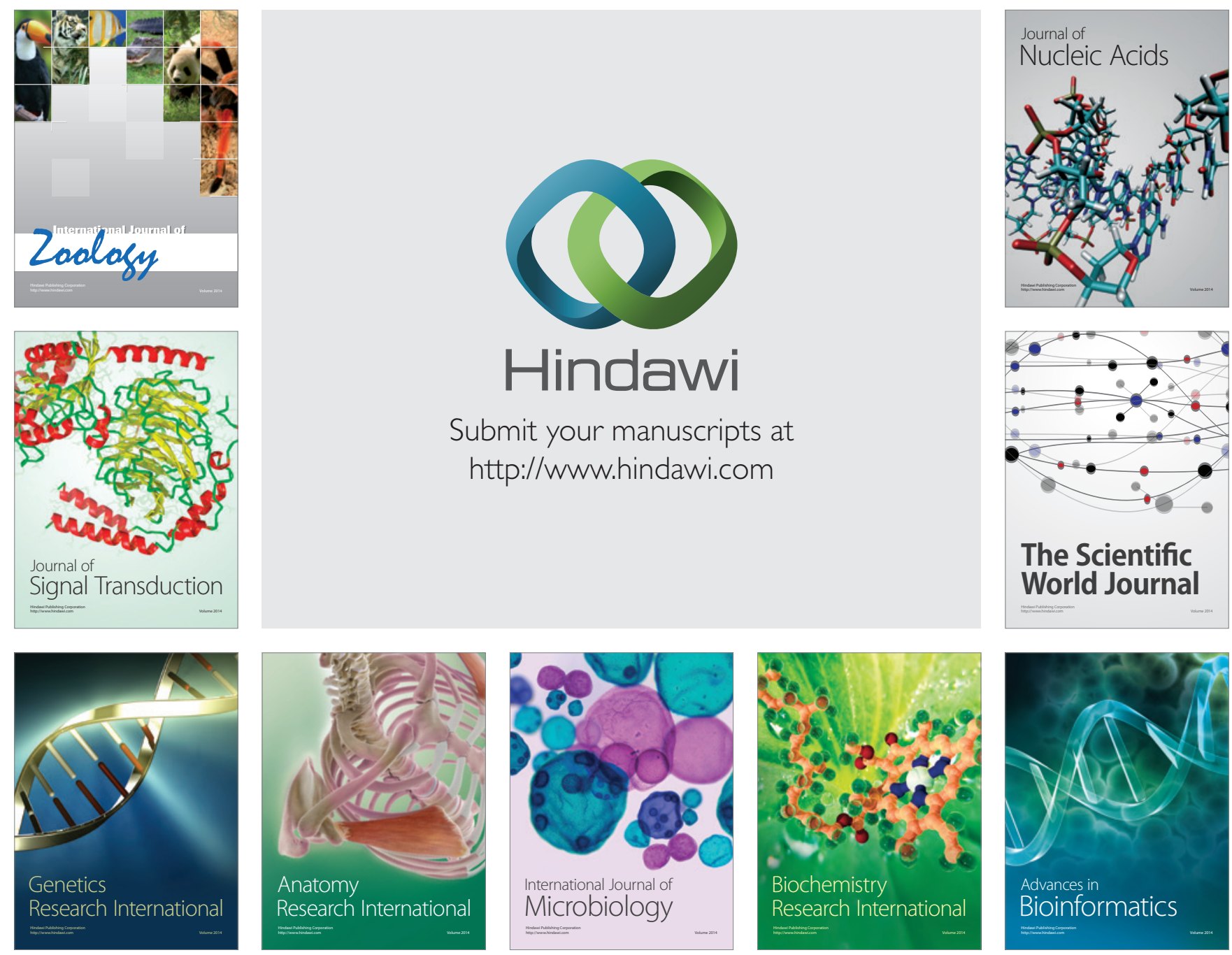

The Scientific World Journal
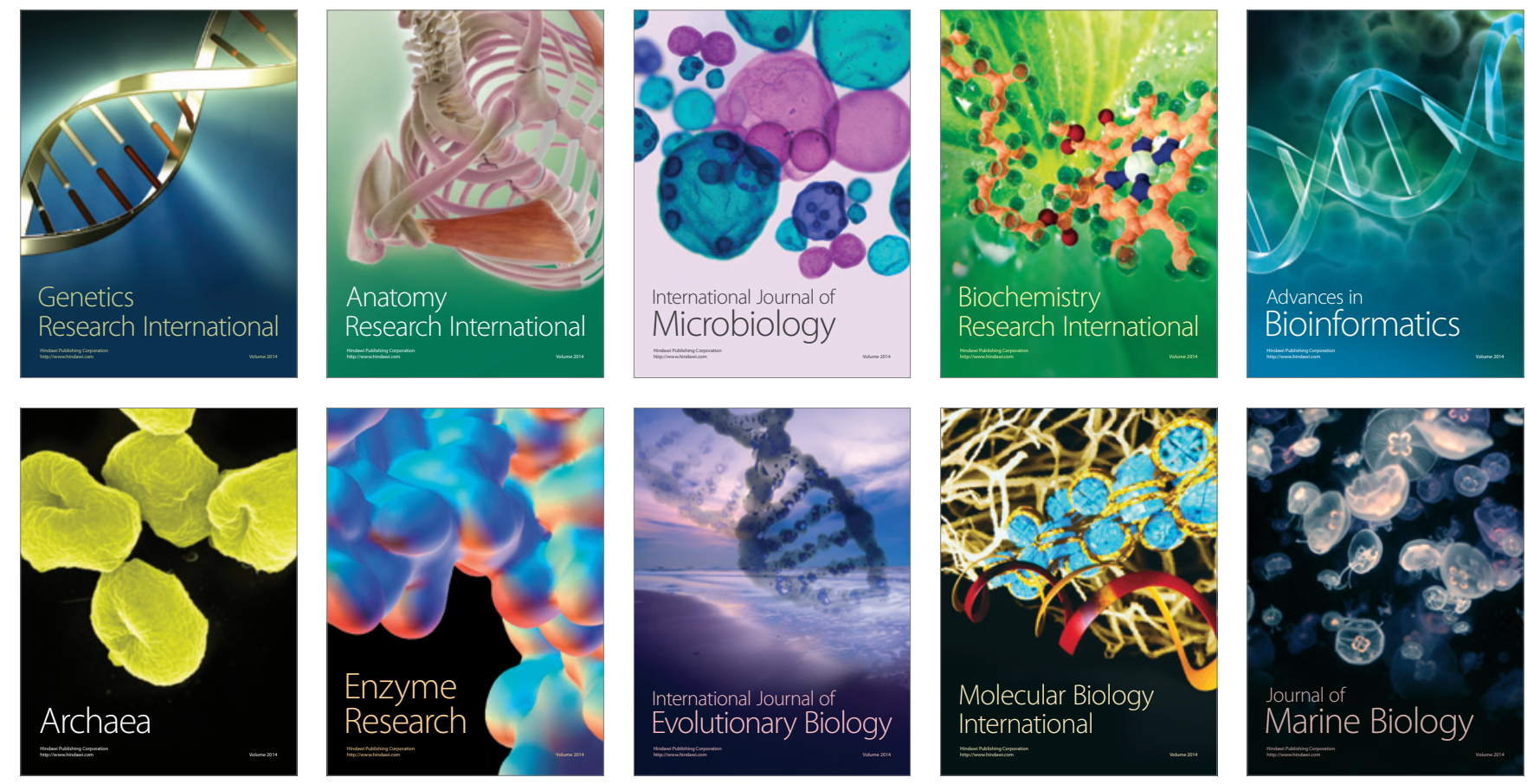